\title{
THE CONDEMNATION OF JEPHTHAH
}

\author{
Tamie S. Davis
}

\begin{abstract}
Summary
This paper argues that literary context, commonly used by evangelicals, and intertextuality, often championed by feminist scholars, are complementary tools for understanding the story of Jephthah and his daughter in Judges 11:29-40. The lack of comment from the narrator on the morality of the story has perplexed many readers but, when viewed together, these approaches build a compelling case for Jephthah's condemnation. The literary context gives warrant to the feminist horror at the events of Judges 11:29-40. Intertextual contrast relating to gender can alert the reader to other differences between the stories which then present Jephthah as an inversion of Abraham: unfaithful and abhorrent to YHWH.
\end{abstract}

\section{Introduction}

In the introduction to Tamar's Tears: Evangelical Engagements with Feminist Old Testament Hermeneutics, Andrew Sloane calls evangelicals to 'engagement not conflict' with feminist readings of Scripture. ${ }^{1}$ This paper attempts to add to that discussion using the intriguing story of Jephthah and his daughter in Judges 11:29-40 as a case study. Perhaps the most vexing aspect of the story is that the narrator does not comment on its morality. Such silence has led to great attention from both evangelical and feminist scholars but there has been little interaction between the two perspectives. It is my contention that this lack of dialogue has impoverished discussion of the story of Jephthah and his daughter. Instead, accessing both evangelical and feminist approaches clarifies the narrator's implied condemnation of Jephthah.

1 Andrew Sloane, Tamar's Tears: Evangelical Engagements with Feminist Old Testament Hermeneutics (Eugene, OR: Wipf and Stock, 2012): xi. 
Cheryl Exum provides a good basic definition for a feminist approach to biblical criticism: 'the concerns of feminism as a political enterprise'. ${ }^{2}$ These concerns include identifying women's voices and overcoming men's control of them. Exum herself contrasts this approach with those who seek to understand 'the biblical text in its own right ${ }^{3}$ which is how we shall use the term 'evangelical'. This is not to say that only those who self-identify as evangelicals seek to understand the text on its own terms; ${ }^{4}$ it is meant only as a broad brushstroke for those who approach Scripture as normative. 'Evangelical' and 'feminist' are also not by any means exclusive labels. In fact, this paper seeks to integrate both perspectives for a cohesive reading of Judges 11:29-40.

\section{Overview of Evangelical and Feminist Scholarship}

Evangelical discussions of Jephthah's character vary: there is not only one evangelical reading of him. For example, Daniel Block's characterisation of Jephthah as a faithful Canaanite is in stark contrast to Michael Wilcock's attempt to exonerate Jephthah. Wilcock argues that Jephthah's vow was foolish and made in haste but that once he had made his vow, he was obligated to fulfil it. In Wilcock's view, 'What he did (the sacrifice of his daughter) is a thing all Scripture condemns; why he did it (in order to keep his word) is a thing all Scripture commends. ${ }^{5}$ For Wilcock, Jephthah is in some sort of ethical dilemma, caught in a difficult situation and doing his best to honour YHWH in such circumstances. In contrast, Block argues that Jephthah's vow was a calculated move, an attempt to manipulate YHWH. Jephthah was not a faithful Israelite, but 'outrightly pagan', a product of a syncretistic religious environment. ${ }^{6}$ His vow to sacrifice his daughter was a 'deadly

2 J. Cheryl Exum, 'Feminist Criticism: Whose Interests Are Being Served?' in Judges and Method: New Approaches in Biblical Studies, ed. Gale A. Yee (Minneapolis: Fortress, 2007): 65-87.

3 Exum, 'Feminist Criticism', 65.

4 See, for example, the fine work of Jewish scholar Amit on the literary composition of Judges. Yaira Amit, The Book of Judges: The Art of Editing (Boston, MA: Brill, 1999.)

5 Michael Wilcock, Judges (Bible Speaks Today; Leicester: Inter-Varsity Press, 1992): 188.

6 Daniel Block, Judges, Ruth (New American Commentary; Nashville: Broadman and Holman, 1999): 367. 
serious expression of devotion', designed to guarantee victory from YHWH as it would the favour of a pagan god. ${ }^{7}$ While Block and Wilcock disagree, such variety is not merely an evangelical idiosyncrasy.

Feminist scholars have also read this story in a range of ways. While Cheryl Exum sees Jephthah as a pathetic character, Pamela Reis finds him to be measured. With Block, Reis sees Jephthah's vow as calculated but with Wilcock, she believes this to be a sign of his piety. She cites Jephthah's reiteration of Israelite history in his pre-battle vow (Judg. 11:30) as evidence that his knowledge of the law precludes his vow from including human sacrifice. ${ }^{8}$ She sees him as dedicating his daughter to YHWH with the understanding that she could redeem herself, as per Leviticus 27:2-4. ${ }^{9}$ In contrast, Exum's view of Jephthah is far less sympathetic. She sees him as a negotiator who fumbles an attempt at manipulation and ends up in an ethical dilemma. ${ }^{10}$ However, his failure to truly struggle with his fate prevents him from attaining 'genuinely tragic proportions'. ${ }^{11}$ Instead, he is a bare shadow of other tragic heroes in the Bible, leaving room for him to be pitied but certainly not admired. Like evangelicals, feminist scholars read the characterisation of Jephthah in a diversity of ways.

Despite this variety among themselves, there are aspects that are unique to the evangelical approach and some that are distinctive of feminist readings. Evangelical scholars have majored on literary context as the main tool for interpreting this story. For example, Barry Webb argues that it is the larger literary structure of Judges that must shape the reading of Judges 11:29-40. He sees the book of Judges as a 'downward spiral', first signalled in Judges 2:18-20, and identifies 5 stages in a cycle that is common to each generation: Israel's apostasy, YHWH's intervention, subjugation by a foreign power, leading to religious and political consequences. ${ }^{12}$ Each of these can be identified

7 Block, Judges, 367.

8 Pamela Tamarkin Reis, 'Spoiled Child: A Fresh Look at Jephthah's Daughter', Prooftexts 17 (1997): 279-98.

9 Reis, 'Spoiled Child', 287.

10 J. Cheryl Exum, Tragedy and Biblical Narrative: Arrows of the Almighty (Cambridge: Cambridge, 1992): 57.

11 Exum, Tragedy, 57.

12 Barry G. Webb, The Book of the Judges: An Integrated Reading (JSOTSup; Sheffield: Sheffield Academic, 1987): 42; See also Terry L Brensinger, Judges (Believers Church Bible Commentary; Pennsylvania: Herald, 1999): 226. 
in the Jephthah narrative: apostasy (10:6); YHWH's intervention (10:7); Ammon is the subjugating foreign nation (10:8-9); the religious consequence is that Israel returns to YHWH (10:10-16); and the political consequence is that Jephthah is elevated in Gilead (11:4-11). ${ }^{13}$

Additionally, each of these cycles has a larger context. Each generation is worse than the last (2:19). Thus the Jephthah cycle begins by underlining how starkly evil Israel has become, listing the various gods they followed (10:6). ${ }^{14}$ This comes after the Gideon story which ended with the construction of a paganised ephod (8:27). Jephthah's conduct can therefore be seen as a further illustration of Israel's descent into Canaanised practice. ${ }^{15}$ Webb argues that this literary structure is the only basis on which to form conclusions about the story. He is suspicious of moving beyond the 'synchronic text' or looking for underlying ideologies, considering these 'tangential'. ${ }^{16}$ Thus, although he nods in the direction of intertextuality by acknowledging E. R. Leach's contrast of Judges 11:29-40 with Genesis 22:1-19, he does not go on to entertain the possibilities this raises, declaring it to be only of 'heuristic value'. ${ }^{17}$

In contrast to this wariness, feminist scholars have readily used intertextuality in order to detect the ideology of the text. Exum says, 'So long as we remain within the boundaries of the literary text itself, the study of women in ancient literature cannot become anything other than the study of men's views of women. ${ }^{, 18}$ She argues that only in stepping outside the ideology of the biblical text can a female voice be heard. One way of doing so is to contrast similar texts that differ in gender. Thus, feminist scholars have given great attention to the contrast between the sacrificed daughter of Judges 11 and the saved son, Isaac, of Genesis 22. It is on the basis of this contrast that Esther Fuchs asks, 'To what extent is the expendability of Jephthah's daughter related to her femaleness?'19 Exum contrasts the pathos of the

\footnotetext{
13 Webb, Judges, 42.

14 Trent C. Butler, Judges (Word Biblical Commentary; Nashville: Thomas Nelson, 2009): 279; Webb, Judges, 41.

15 Block, Judges, 378.

16 Webb, Judges, 38.

17 Webb, Judges, 228.

18 J. Cheryl Exum, Fragmented Women: Feminist (Sub)versions of Biblical Narratives (JSOTSup; Sheffield: Sheffield, 1993): 9.

19 Esther Fuchs, 'Marginalization, Ambiguity, Silencing: The Story of Jephthah and His Daughter', Journal of Feminist Studies of Religion 5 (1989): 35-45.
} 
Genesis 22 scene with the jarring events of Judges $11 ;{ }^{20}$ Phyllis Trible likewise believes that the tragedy of Jephthah's daughter receives extra poignancy when read alongside Isaac's fate. ${ }^{21}$ Barbara Miller argues that an intertextual reading of the two stories raises questions about how the relationship of fathers to the Deity affects their offspring. ${ }^{22}$ Suspicious of the goals of the story in its current form, then, feminist scholars use intertextual contrast to expose an androcentric ideology.

These differences between evangelical and feminist perspectives on Judges 11:29-40 are not merely incidental. They are motivated by different goals and divergent attitudes towards Scripture. While this provides fodder for these scholars to be discussion partners, there has been little dialogue and thus little mutual benefit or contribution. However, as Richard Briggs notes 'feminists and evangelicals both, in different ways, bring some aspects of the text to life and obscure others ... One might at least wonder whether an interpreter alert to both evangelical and feminist insights might not be better placed than one who has only one or the other agenda. ${ }^{23}$ What riches might be discovered by considering both evangelical and feminist perspectives on Judges 11:29-40? As we will see, reading with the narrator in literary context will reveal many of the same concerns as feminist scholars themselves. Similarly, asking the intertextual gender question can shed light on the text to enrich an evangelical reading. Moreover, the question of the characterisation of Jephthah is settled by viewing the literary context and the intertextual comparison together, compelling the reader to view Jephthah negatively.

20 Exum, Tragedy, 52.

21 Phyllis Trible, Texts of Terror: Literary Feminist Readings in Biblical Narratives (Overtures to Biblical Theology; Philadelphia: Fortress, 1984): 101.

22 Barbara Miller, Tell It on the Mountain: The Daughter of Jephthah in Judges 11 (Interfaces; Minnesota: Liturgical Press, 2005): 38.

23 Richard S. Briggs, 'Hermeneutics by Numbers? Case Studies in Feminist and Evangelical Interpretation of the Book of Numbers' in Tamar's Tears: Evangelical Engagements with Feminist Old Testament Hermeneutics, ed. Andrew Sloane (Eugene, OR: Wipf and Stock, 2012): 65-83. On a more personal note, Williams thanks her feminist discussion partners for helping her to see issues she did not expect and the hermeneutical clarity these brought, even if she 'was not entirely persuaded by some of their analyses and conclusions.' Jenni Williams, 'Adding Insult to Injury? The Family Laws of Deuteronomy’ in Tamar's Tears, 84-111. 


\section{Literary Context for Feminists}

Feminist readings of the story of Jephthah out of its literary context are not without merit. There is good evidence to suggest that the story of Jephthah stands as its own literary unit and perhaps a separate literary work. For example, it is bracketed by the inclusio of 'Jephthah vowed a vow' (11:30) and 'he did to her according to the vow he vowed' (11:39), with 11:39b-40 acting as an epitaph. ${ }^{24}$ However, independent composition does not preclude the story from being artfully included by the author of Judges to suit his purposes. ${ }^{25}$ In fact, David Janzen argues that the theme of the story is consistent with the theological motif of Judges, that 'when Israel worships like foreigners, it will act like foreigners'. ${ }^{26}$

We have already seen Webb's literary argument for the cycles of the 'downward spiral' of Judges and indeed, as the book proceeds, Israelite

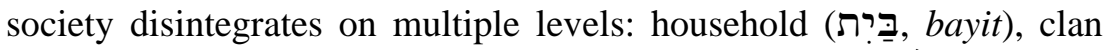

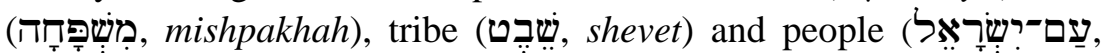
am Yisrael). ${ }^{27}$ This concept is not foreign to feminist scholarship; for example, Trible sees Judges as a 'progression from domestic tranquillity to utter degradation'. However, this observation is tangential to her argument and does not provide her with reason to soften her hermeneutic of suspicion. ${ }^{28}$ Yet, this is the very point at which a focus on literary context can provide a helpful interpretative paradigm for feminist scholars to access. If Judges itself presents a

24 My own translations are used throughout this paper.

25 Block, Judges, 49; Israel Mehlman, 'Jephthah's Daughter', Jewish Biblical Quarterly 35 (1997): 73-78.

26 David Janzen, 'Why the Deuteronomist Told about the Sacrifice of Jephthah's Daughter', JSOT 93 (205): 339-57.

27 Gordon Oeste, 'Butchered Brothers and Betrayed Families: Degenerating Kinship Structures in the Book of Judges', JSOT 35 (2011): 295-316.

28 Trible, Texts of Terror, 50; similarly, other feminists who have used literary context have not accessed its full benefits. For example, Lapsley approaches the text attending to women's words, the narrator's perspective and 'textual worldview'. However, she doesn't deal with Judges 11. Jacqueline E. Lapsley, Whispering the Word: Hearing Women's Stories in the Old Testament (Louisville: Westminster John Knox, 2005): 2. Klein's study of irony in Judges sees a movement throughout the book as a whole. However, to the extent that her goal is to identify a literary method (irony), she does not draw out the theological implications. Lillian R. Klein, The Triumph of Irony in the Book of Judges (JSOTSup; Sheffield: Almond, 1988): 11-21, 192. Likewise, Schneider is concerned to examine how Judges functions as a unified literary document but the focus is on identifying themes in the book as a whole rather than bringing those to bear on particular episodes, such as Judges 11:29-40. Tammi J. Schneider, Judges (Berit Olam; Collegeville, Minnesota: Liturgical, 2000): xiii. 
'downward spiral', then the further the book proceeds, the greater the warrant for condemnation of the events it presents. Thus, far from being at odds with feminist concerns, literary context provides the basis to see Judges as critiquing Israelite leaders and society as deeply flawed.

This critique of Israelite society becomes focused on specifically feminist concerns once attention is given to gender, because it is the lives of women that are a vehicle for exposing the nation's disintegration. We begin with Israelite women. Consider the honour afforded Achsah whose peculiar request for both land in the Negev and the upper springs is granted (1:11-15). We then meet Deborah who is judging Israel, settling their disputes and wisely negotiating the war effort (Judges 4). Likewise, it is a woman, Jael, who delivers Israel from Sisera, with Barak's weakness and lack of faith being exposed by the faithfulness and courage of both Deborah and Jael. Later, the angel of the Lord appears not to Manoah but to his wife first, bringing the news of Samson's birth and impending leadership (Judges 13). While Manoah panics at the thought of having seen God (13:22), his wife displays wisdom, faith and poise. These relatively positive images of women differ from the cowardice and faithlessness of their male compatriots. However, as Judges continues, Israelite women become increasingly sidelined while foreign women become more prominent.

The first mention of foreign women refers to Israelites intermarrying with the daughters of the nations around (3:6), and is followed directly by the statement that 'Israel did evil in the eyes of the Lord'. However, it is not until Samson's story that we see direct consequences of this, both in his legendary affairs with foreign women (14:2-3; 15:1-2; 16:1) and in his capitulation to Delilah (16:15-21). These examples of intermarriage illustrate Israel's increasing syncretism and are accompanied by the degeneration of the fate of women in Israel. Israelite women only reappear during the tragic situation of the concubine, the civil war and the problem of wives for the Benjamites (Judges 19-21). This bloody tale sees one woman cruelly abandoned to a mob and later dismembered; non-virgin women of Jabesh Gilead slaughtered; and virgin women given to Benjamites, the very men who murdered the concubine. As Israelite society disintegrates, so too does the wellbeing of women.

Nicholas Ansell observes that alongside this degradation is a growing absence of God, a withdrawal of God after the Israelites have 
entered into covenant with the former inhabitants of the land and their false gods. ${ }^{29}$ He wonders whether the horrific events of Judges 19 are God's refusal to bless the Israelites. The character of moral decay in Israel is not only sociological, then, but religious. Another aspect of the 'downward spiral' is the presentation of these atrocities against women as a function of a society that has forgotten Yahweh. These acts are foreign to faithful Israel and God's way for them. On their own, each of these stories read as a horrific report of mistreatment of women. Feminist scholars have rightly sought to expose such abuse as atrocious. As part of the literary structure, however, they are shown to be abhorrent not only to feminists but also to the narrator, and, by extension, to God.

Maltreatment of women accompanies the fall of the nation; it conveys the terrible extent of the moral decay of Israelite men and society. When it comes to reading the story of Jephthah, then, located in the middle of Judges, we may have room to read the daughter positively but certainly no warrant to view Jephthah as faithful. The views of Exum and Block, which as we saw earlier, present Jephthah respectively as pathetic and syncretistic, appear to have strong warrant at this point. Indeed, Trible's assessment of him as 'faithless' is appropriate. $^{30}$ To read Jephthah instead as faithful would be inconsistent with the overall shape of Judges. The concern of evangelical scholars for literary context provides helpful parameters here. Unfaithful Jephthah is representative of Israel's own turn to apostasy; to construe him otherwise would present a sudden upturn in the downward spiral. Such parameters as these are not at odds with feminist concerns. Jephthah's actions are by no means commendable; the death of his daughter is in no way endorsed. These are part of a loathsome era of Israel's history and one which literary criticism exposes rather than conceals. Maltreatment of women is representative of the extent of the apostasy of Israel. Thus a feminist perspective can share common ground with evangelical literary critics in viewing the abuse of this woman as inherently foreign to faithful Israel, and abhorrent to God.

29 Nicholas Ansell, 'This Is Her Body... Judges 19 as Call to Discernment' in Tamar's Tears, 112-71.

30 Trible, Texts of Terror, 103, 106. 


\section{Intertextuality for Evangelicals}

Thus far we have seen that reading Judges 11:29-40 in literary context does not cut against feminist concerns. Indeed, it may even lend credence to them. What contributions might the feminist interest in intertextuality offer to evangelicals? I will return to this shortly; however, evangelical scholars sometimes object to intertextual comparison because of its supposed unreliability. ${ }^{31}$ Is the selection of texts merely arbitrary? Mark Powell argues that with suitable controls, it need not be. He identifies three criteria for determining the plausibility of intertextual dependence: repetition; thematic coherence; and the likelihood of the author's or readers' knowledge of the alluded text. ${ }^{32}$ Indeed, there are cases of evangelical scholars who have used intertextuality to identify elements that enhance a reading of Scripture as a coherent unfolding story. ${ }^{33}$ It may be then, that a suitably disciplined intertextual reading may fit into evangelical concerns to read Scripture canonically.

I therefore turn here to establish that there are plausible linguistic, thematic and stylistic links between Judges 11:29-40 and Genesis 22:119. Linking these two texts together is not a new idea. From PseudoPhilo to Peter Abelard to present day scholars, ${ }^{34}$ the relationship between Judges 11:29-40 and Genesis 22:1-19 has been observed so frequently that Mikael Sjöberg merely notes it and moves on. ${ }^{35}$

31 Webb, for example, limits 'the narrative meaning of the text (its meaning as story) ... to consist in the interaction of persons and events within the unfolding plot'. Webb, Judges, 36.

32 Mark Allen Powell, Chasing the Eastern Star: Adventures in Biblical ReaderResponse Criticism (Louisville: Westminster John Knox, 2001): 101-102.

33 At a most basic level, Brown points out that it is uncontroversial to see that Exodus assumes some knowledge of the story of Genesis (e.g. Exod. 1:1, 8). Jeannine $\mathrm{K}$. Brown, Scripture as Communication: Introducing Biblical Hermeneutics (Grand Rapids: Baker Academic, 2007): 226. Similarly, Richard Bauckham confidently reads Abraham as the 'particular' that infers the 'universal' of God's mission. Richard Bauckham, Bible and Mission (Paternoster: Carlisle, 2003): 17, 28.

34 Elisheva Baumgarten, “"Remember that Glorious Girl”: Jephthah’s Daughter in Medieval Jewish Culture', Jewish Quarterly Review 97 (2007): 180-209; Tal Ilan, 'Gender Difference and the Rabbis: Bat Yiftah as Human Sacrifice' in Human Sacrifice in Jewish and Christian Tradition, ed. Karin Finsterbusch, Armine Lange and K. F. Diethard Römheld (Numen Book Series; Leiden: Brill, 2007): 175-90.

35 Mikael Sjöberg, Wrestling with Textual Violence: The Jephthah Narrative in Antiquity and Modernity (Bible in the Modern World; Sheffield: Sheffield Phoenix, 2006): 65. 
However, while this relationship has been reiterated, its implications could be developed more substantially.

Linguistically, the reference to an only child is significant. Isaac is the יחָיחיד, yakhid 'the only one'; Jephthah's daughter is referred to with the feminine form יחיחירדָ, yehkidah.This rare construction occurs three times in the Isaac story (Gen. 22:2, 12, 16) and at the critical point of clarity in Judges 11:34, at which it is revealed that the daughter is to be the sacrificial victim. Further emphasis is given in Judges 11:34 by the superfluous explanation, 'apart from her he had neither son nor daughter'.

Thematically, there are significant connections between the two stories. As we have just noted, the offspring in both cases are only children. In their narrative contexts, both children are the sole descendants of their parents, the beloved child and the only hope of the continuation of their line. ${ }^{36}$ The parent on view in both cases is the father and he is to be the sacrificer (Gen. 22:2, 10; Judges 11:31, 36, 39). In both cases, the sacrifice has a religious character: it is to fulfil an obligation to God, and the child is to be sacrificed to God. ${ }^{37}$ Both stories hence play with questions about the duty to protect family coming into conflict with loyalty to God. Which allegiance is stronger? How should the father adjudicate two conflicting moral imperatives? ${ }^{38}$

Stylistically, both texts contain dialogue between father and child. Webb locates the dramatic tension in the discussion between Jephthah and his daughter; ${ }^{39}$ dialogue is also central in constructing the tension of Genesis 22:1-19. ${ }^{40}$ Both stories are suspenseful, leaving the reader wondering what will happen - will the child be saved or will he or she indeed be sacrificed?

With such symmetry on linguistic, thematic and stylistic levels, it seems appropriate to conclude, as Miller does, that 'one can hardly

\footnotetext{
36 Technically, Isaac is not an only child, because he has a half brother Ishmael. However, there is no acknowledgement of this in Genesis 22:1-19.

37 This is where these two stories stand apart from the story of Jonathan in 1 Sam. 14:46. The tone of that story is more social than religious and Jonathan is not an only child.

38 James Paul Gee, 'Memory and Myth: A Perspective on Narrative' in Developing Narrative Structure, ed. Allyssa McCabe \& Carole Peterson (New Jersey: Lauren Erlbaum, 1991): 1-26, esp. 7.

39 Webb, Judges, 73.

40 Laurence H. Kant, 'Restorative Thoughts on an Agonizing Text: Abraham's Binding of Isaac and the Horror of Mt Moriah (Genesis 22): Part 2', Lexington Theological Quarterly 38 (2003): 161-94.
} 
read the account of Jephthah's daughter without reflecting on a similar narrative in which Abraham nearly sacrifices his son Isaac'. ${ }^{41}$ As the two stories call each other to mind, a strong intertextual relationship emerges. This is not an unfamiliar concept to evangelical readers. Robert Alter's notion of type settings at least alerts us to the possibility of patterns and recall in biblical narrative. ${ }^{42}$ Similarly, Byron Wheaton observes that repetition is a key literary device which can parallel one text to another using 'a speech, a description ... a pattern, themes, characters, vocabulary and phraseology' ${ }^{43}$ Such allusion can affect the meaning of a text by bringing previous events to mind. Indeed, we have seen the repetition of vocabulary, themes, dialogue and motifs in Judges 11:29-40 and Genesis 22:1-19.

The allusion identified here does not imply direct parallelism between the two texts. In this case, while there are remarkable similarities between the two texts, there are also profound differences. For example, although Isaac and the daughter are both the only children of their fathers, Isaac is the child of promise in a unique way. His life or death carries the fulfilment or unfulfillment of God's promise to Abraham. No such promise is present in the Jephthah narrative. Similarly, God's oath to Abraham in Genesis 22:15-18 affirms those of Genesis 12:1-3 and Genesis 15:5, and continues to shape the rest of the book. Nevertheless, what we have noted here is the presence of allusion. One text may recall particular aspects of the other without referencing every dimension of the original text.

What is the nature of the intertextual relationship between these two texts, then? Which story appropriates the other and to what extent? Which story should be read as the original and which as drawing on the other? Genesis is generally dated earlier than Judges, making it the earlier source. However this does not necessarily mean it is the earlier story, since both probably existed in oral story format prior to being written down. ${ }^{44}$ However, the dating of the written form alerts us to

\footnotetext{
41 Miller, Tell It, 35.

42 Robert Alter, The Art of Biblical Narrative (New York: Basic Books, 1981): 49. I am not suggesting that Genesis 22 and Judges 11 are a type setting. Two texts are not enough to draw such form-critical conclusions. I am merely pointing out that evangelical scholars have previously benefited from intertextual readings.

43 Byron Wheaton, 'Focus and Structure in the Abraham Narratives', TrinJ 27 (2006): $143-62$.

44 Editing of Judges is normally dated to the exilic or late pre-exilic era. Brensinger, Judges, 230; Block, Judges, 64. Editing of Genesis has at times been dated to this
} 
another relevant tool for assessing the relationship of these two texts, that is, canonical criticism. In reading Scripture as an unfolding story, Abraham comes before Jephthah; read in canonical context, Genesis precedes Judges just as the Pentateuch precedes the Prophets. In terms of how the scriptural story unfolds, the Abraham story is the assumed story. While the historical relationship between the two texts remains ambiguous, on a literary level it seems best to see Judges 11:29-40 as drawing on Genesis 22:1-19 rather than the other way around. Judges 11:29-40 needs to be read in the light of Genesis 22:1-19. Additionally, from a biblical-theological perspective, Abraham is something of a paradigmatic figure in the canon. ${ }^{45}$ The Abrahamic promises are intimately related to the role of Israel within God's purposes. Any failure in that role raises questions about how the promises are to be fulfilled. This includes the degradation of Israel profiled in Judges: such a state endangers the fulfilment of the promises to Abraham. Theologically, then, there is reason to read Genesis 22:1-19 as the assumed story in Judges 11:29-40.

Having established a plausible connection between the two texts, we are in a position to explore the insights that feminist scholars have gleaned from comparing the two and to consider how they may benefit an evangelical reading. Fuchs observes the silence of YHWH in Judges 11 in comparison with his instigation of the events of Genesis 22:1$19 .^{46}$ While YHWH is at the centre of the Genesis 22:1-19 narrative, he is effectively sidelined in Judges 11:29-40, a mere indirect object. ${ }^{47}$ Fuchs concludes that the narrator of Judges has suppressed YHWH's voice to save him from the uncomfortable conclusion that he has some responsibility for the daughter's death. Trible concurs that YHWH's silence is significant. She contrasts the locus of initiative in both stories: with Jephthah and his vow in Judges 11:29-40 but with God and his command in Genesis 22:1-19. Trible also highlights the relationship of the father to the Deity in each story: while Abraham has faith that God would provide a sacrifice, Jephthah fails even to appeal

period as well but there is significant evidence for its redaction during the United Kingdom. Robert Alter, The Five Books of Moses (New York: WW Norton, 2004): ix; Gary A Rendsburg, The Redaction of Genesis (Indiana: Eisenbrauns, 1986): 119.

45 Richard Bauckham, Bible and Mission, 48-49; Andreas J. Köstenberger and Peter T. O'Brien, Salvation to the Ends of the Earth: A Biblical Theology of Mission (New Studies in Biblical Theology; Nottingham: Apollos, 2001): 32.

46 Fuchs, 'Marginalization', 196.

47 Fuchs, 'Marginalization', 196. 
to the Deity. ${ }^{48}$ Thus Abraham and Jephthah are not parallel characters but mirror images of each other. However, in her view, this does not acquit YHWH of his failure to save the daughter. She asks, 'my God, my God, why hast thou forsaken her?" ${ }^{49}$ Both Fuchs and Trible conclude that YHWH is implicated in the sacrifice of Jephthah's daughter because he failed to intervene for her as he did for Isaac. The key difference is seen to be gender, thereby implicating YHWH in the androcentric ideology of the text.

However, this is not the only conclusion available. Evangelical scholars can benefit from feminist scholars' intertextual observations without necessarily accepting their conclusions. ${ }^{50}$ This feminist indictment of YHWH is driven by the assumption that the biblical texts are inherently androcentric, as we saw earlier. Thus, feminist scholars most often read these texts as upholding patriarchal values: the son is preserved and the daughter sacrificed. The stories mirror each other, and the outcome for the child relates to his or her gender. However, I contend that while Genesis 22:1-19 does celebrate the preservation of the son, the sacrifice of the daughter in Judges 11:29-40 is presented as anti-Israelite and anti-YHWH. While the sacrifice of the daughter is indeed a significant inversion of the son's preservation, this is not the only difference between the two stories. A feminist observation of this inversion is helpful, drawing our attention to the difference gender makes, but it is incomplete.

The stories also bear significant differences on the level of structure and pacing. In terms of pacing, Isaac's near sacrifice is narrated in full. The detail in Genesis 22:9-11 is striking as the narrator lingers over the action: the building of the altar; the arranging of the wood; laying Isaac on the altar; the raising of the knife. This serves to slow down the narrative and build suspense for the climactic moment. ${ }^{51}$ The narration of the sacrifice of Jephthah's daughter, on the other hand, takes only

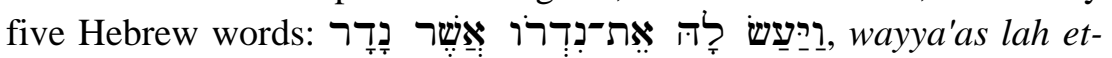
nidiro asher nadar, 'and he did to her his vow which he had vowed'

\footnotetext{
48 Trible, Texts of Terror, 102.

49 Trible, Texts of Terror, 105.

50 For example, Miriam Bier notes with feminists the silence of the Deity in 2 Sam. 13:1-22 but resists their attempts to read this as indicative of either the Deity's absence or complicity in Tamar's suffering. Rather, she concludes it is a sign of God's refusal to be party to such evil, thus condemning it. Miriam J. Bier, 'Colliding Contexts: Reading Tamar (2 Sam. 13:1-22) as a Twenty-First Century Woman' in Tamar's Tears, 171-90.

51 Trible, Texts of Terror, 105.
} 
(11:39). Several commentators have noted the difference, wondering whether the cursory treatment of the sacrifice in Judges 11 functions either to spare the reader some discomfort or reveals the narrator's own discomfort with the outcome. ${ }^{52}$

This difference in pacing is reflected also in the structure of the story. James Gee notes that Judges 11:29-40 read forwards reflects Genesis 22:1-19 read backwards. His observations are reproduced in the table below. ${ }^{53}$

Gee's structure sharpens our understanding of the stories' intertextuality: Judges 11:29-40 is not merely drawing on Genesis 22:1-19. It is its inverse. What feminist scholars have observed about the fate of the children and the character of the fathers is also true of the literary substructure: they are mirror images. This suggests that the literary technique in play should alert us to the ideology of Judges 11:29-40.

A contemporary analogy may help here. Imagine a fairy-tale that begins, 'Once upon a time, there was a captive prince who needed a brave princess to rescue him.' Immediately, we recognise the story: this is a fairy-tale, but not as we would normally hear it. Though there's something familiar about this story, we're aware that it will not look like other fairy-tales because the gender of the usual characters is inverted. It is the ending of the story that will reveal whether this inversion is positive or negative: do they end up 'happily ever after' or is the story one of doom? If the latter, we quickly ascertain that the whole story, including its gender inversion, is a negative version of what we expected. In the case of Judges 11:29-40, it is Genesis 22:1-19 which is the expected story and Judges 11:29-40 which plays with the ideology of the former. While the backdrop of Genesis 22:1-19 may lead us to expect to see a faithful man and a faithful God, instead, we are left with a God who is sidelined as the unfaithful man treats him like a pagan deity. One cue that highlights this is the gender of the

Trible, Texts of Terror, 105; Mieke Bal, Death and Dissymmetry: The Politics of Coherence in the Book of Judges (Chicago: University of Chicago, 1988): 110; Exum, Tragedy, 52; Block, Judges, 375; Brensinger, Judges, 135; Fuchs, 'Marginalization', 197. If the latter option, the narrator's brevity may function to magnify the implications of the Deity's silence: an expression of horror at the events. See Bier, 'Colliding Contexts', 187; Wenham notes a similar pattern in Gen. 3:6-8 where more detailed descriptions are succeeded by a short series of terse steps. See Gordon J. Wenham, Genesis 1-15 (Word Biblical Commentary; Waco: Word, 1987): 75.

53 Gee, 'Memory and Myth', 6-7; I have added in the Bible references. 
children and their divergent fates and so Judges 11:29-40 functions as a sad upending of the faithfulness of Abraham. The inversion is a literary technique that casts this whole story in a negative light.

Jephthah (read forward)

Judges 11:30-31

Man gives his word to God (vows) that God will have a dead sacrifice (= his daughter)

if (in future) God gives Man a gift (= God allowed killing of foreigners) But only daughter replaces animal.
Abraham (read backward)

Genesis 22:16-18

God gives his word to Man (promises) that Man will have many live descendants because (in past) Man gave God a gift . (= Man is willing to kill son). But animal replaces only son.

Thus Man loses only child by actually Thus Man gains many relatives by killing foreigners. Judges 11:32-33 potentially killing only child. Genesis 22:10

Jephthah does slay foreigners. Judges 11:34

Abraham starts to slay son. Genesis 22:13

A child 'happens' to come out; Jephthah's only child replaces an animal.

Judges 11:35-36

A ram 'happens' to be there; the animal replaces Abraham's only child.

Genesis 22:7-8

Father tells child she is the offering.

Child tells father to provide the offering he has promised.

Judges 11:37-39

Child asks father where the offering is. Father assures child that God will provide the offering he wishes. Genesis 22:4

Father and son go up the mountain together, leave companions behind. Genesis 22:2

God commands (future) father to kill only child (son).

\section{The Condemnation of Jephthah}

I began this paper by noting that even among themselves, evangelical and feminist scholars have failed to reach consensus about Jephthah as a positive or a negative character. However, as feminist scholars consider the literary context of Judges 11:29-40, the story can be seen as part of the downward spiral of the book as a whole. This provides significant impetus to read Judges $11: 29-40$ as a negative story. Likewise, as evangelical scholars explore the implications of gender in Judges 11:29-40 and Genesis 22:1-19, it is possible to see a literary technique which functions to present Jephthah in a negative light. Evangelical scholars hold one piece of evidence for Jephthah's 
condemnation and feminist scholars have the key to another. When viewed together, the evidence becomes much stronger. That is to say, Jephthah is condemned not only by the story's context but also by the storytelling itself. While the structure of Judges invites us to read Judges 11:29-40 as part of the downward spiral of Judges as a whole, the inversion technique invites us to read this part of the book, Judges 11:29-40, against the backdrop of Abraham's faithfulness and to see this entirely reversed. Jephthah is thus portrayed as the anti-hero of faith, the un-Abraham.

The literary inversion technique seen above exists on a number of different levels, not only the inversion of gender. However, a daughter being sacrificed instead of a son is one inversion that contributes to the overall upending of the story. Drawing attention to this gender inversion helps us to notice the other points at which Judges 11:29-40 is contrasted with Genesis 22:1-19, thereby seeing it as a condemnation of Jephthah and Israel. At this point, a feminist reading that draws attention to the gender inversion coheres with reading the story in literary context. Asking what difference gender makes to the story can lead us to discover a literary technique that is not only compatible with a reading in literary context but even enhances it.

In light of literary context and intertextual contrast, the impulse to redeem Jephthah's reputation, seen in Wilcock and Reis, is misguided. Likewise, the feminist suspicion that biblical texts inherently oppress women finds little warrant in this text. Reading with the narrator of Judges against the backdrop of Genesis 22:1-19, we are horrified by what happens to Jephthah's daughter and see Jephthah's actions as abhorrent to YHWH. The narrator has no need to justify Jephthah because Jephthah is presented as utterly despicable. Neither ought we, as readers, attempt to exonerate him. There is no excuse. In this sense, the text is just as feminist as the feminists, condemning the sacrifice of Jephthah's daughter as an abominable exemplar of unfaithfulness. 